«Системні технологіï» 1 (132) 2021 «System technologies»

DOI 10.34185/1562-9945-1-132-2021-03

УДК 004.35

Є.С. Сулема, М.В. Онай, А.І. Дичка

\title{
ЗАБЕЗПЕЧЕННЯ ЗАВАДОСТІЙКОСТІ БАГАТОКОЛІРНИХ ШТРИХКОДОВИХ ЗНАКІВ НА ОСНОВІ ПОЛЯ $G F\left(p^{m}\right)$
}

Анотація. Розроблено методику синтезу символік багатоколірних високонадійних штрихових кодів для систем автоматичної ідентифікації. Запропоновано дворівневу систему забезпечення завадостійкості багатоколірних штрихкодових зображень, у якій на нижньому структурному рівні (рівні штрихкодових знаків) застосовуються многозначні неповні коди Хемінга, а на верхньому (рівні штрихкодової позначки) - коди Ріда-Соломона. Виконано оцінювання коректувальних можливостей многозначних неповних кодів Хемінга при їх використанні у штриховому кодуванні даних. Розглянуто особливість виконання операцій у скінчених полях виду $G F\left(p^{m}\right)$ при реалізації прочедур кодування-декодування даних в системах автоматичної ідентифікації на основі багатоколірних штрихових кодів.

Ключові слова: багатоколірний штриховий код, многозначні коди Хемінга, автоматична ідентифікація, операції у скінченних полях.

Вступ. Використання штрихових кодів є одним з найпопулярніших способів швидкого введення даних у комп’ютерну систему [1, 2]. 3 часу винайдення перших штрихових кодів минуло декілька десятиліть, однак інтерес до штрихкодової технології автоматичної ідентифікації не знижується.

Останніми роками спостерігається стійка тенденція до використання багатоколірних штрихових кодів [3-5]. Причина очевидна: прагнення підвищити інформаційну щільність - на одиниці площі носія без зміни геометричних розмірів елементів штрихкодового зображення подавати більшу кількість інформації, ніж це дозволяють традиційні чорно-білі штрихові коди [6, 7].

Однак, при цьому ускладнюються процеси розпізнавання та декодування штрихкодових зображень [8, 9]. Серед причин: особливості зчеплення барвників (фарб) з поверхнею носія (згортання або розпливання фарби); змішування кольорів на межі сусідніх елементів з різним забарвленням; спотворення геометричних розмірів елементів штрихкодового зображення під час зчитування внаслідок певних оптичних ефектів тощо [4, 7].

(C) Сулема Є.С., Онай М.В., Дичка А.I., 2021 


\section{«Системні технології» 1 (132) 2021 «System technologies»}

Тому, для надійного зчитування з об’єкта багатоколірних штрихових кодів необхідно забезпечувати завадостійкість штрихкодових зображень. Оскільки структурно штрихкодова позначка складається зі штрихкодових знаків (ШКзнаків), то для досягнення належного рівня надійності зчитування даних слід створювати багатоколірні штрихкодові зображення так, щоб властивість завадостійкості забезпечувалась не лише на рівні усієї штрихкодової позначки, а й на рівні ШК-знаків - мінімальних структурних одиниць.

Для забезпечення завадостійкості на рівні усієї штрихкодової позначки зазвичай застосовують коректувальні коди, що здатні виправляти багатократні помилки - код Боуза-Чоудхурі-Хоквінгема (БЧХ) або код Ріда-Соломона [10]. У цьому дослідженні пропонується застосовувати многозначний (недвійковий) код Хемінга для забезпечення завадостійкості на рівні ШК-знаків.

У випадку застосування многозначних коректувальних кодів для реалізації процесів кодування-декодування даних використовують математичний апарат скінченних полів (полів Галуа) [11, 12].

Розрізняють два види скінченних полів: поля виду $G F(p)$ - коли кількість $(p)$ елементів поля є простим числом, тоді операції виконують за модулем $p$; поля виду $G F\left(p^{m}\right)$ - коли кількість $\left(p^{m}\right)$ елементів поля є степенем простого числа, тоді операції виконують за модулем незвідного многочлена степеня $m$ [13].

Розглянемо застосування многозначних ( $q$-кових) кодів Хемінга $(q>2)$ для забезпечення завадостійкості багатоколірних ШК-знаків коли $q$-кількість використовуваних кольорів для розфарбовування знаків, є степенем простого числа, тобто, коли $q=p^{m}$, де $p \geqslant 2, m \geqslant 2$ (випадок $q=p \epsilon$ предметом іншого дослідження).

Постановка задачі. Штриховий код має свій набір ШК-знаків, кожен 3 яких позначає один символ комп'ютерного алфавіту. Цей набір ШК-знаків називають символікою штрихового коду [3, 4].

Нехай необхідно створити символіку завадостійкого багатоколірного двовимірного (матричного) штрихового коду з параметрами $q$, $s: q$-кількість використовуваних кольорів для розфарбовування елементів ШК-знака, причому $q \epsilon$ степенем простого числа; $s$-кількість елементів (чарунок) у ШК-знаках (рис. 1).

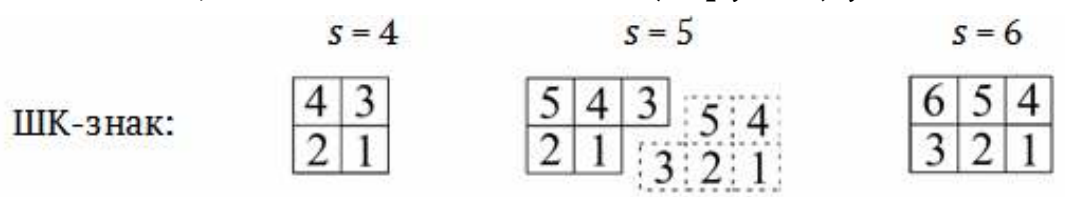

Вектор ШК-знака: $\quad Z=\left(z_{1} z_{2} z_{3} z_{4}\right) \quad Z=\left(z_{1} z_{2} z_{3} z_{4} z_{5}\right) \quad Z=\left(z_{1} z_{2} z_{3} z_{4} z_{5} z_{6}\right)$

Рисунок 1 - Приклади структур ШК-знаків при s = 4, 5, 6 


\section{«Системні технологіï» 1 (132) 2021 «System technologies»}

Кожен елемент ШК-знака може бути розфарбований будь-яким з $q$ кольорів, які позначатимемо цифрами: $0,1,2, \ldots, q-1$. ШК-знаку, що складається $3 s$ елементів, поставимо у відповідність цифровий еквівалент - вектор ШК-знака $Z=\left(z_{1} z_{2} \ldots z_{s}\right)$.

Оскільки $z_{i} \in\{0,1,2, \ldots, q-1\}$, то розряди слова $Z$ слід розглядати як многозначні (недвійкові) символи. Для того, щоб ШК-знак був завадостійким, його цифровий вектор $Z$ має бути кодовим словом коректувального коду, здатного виправляти та/або виявляти помилки.

Якщо таким коректувальним кодом обрати $q$-ковий код Хемінга, $q>2$, і на його основі будувати символіку штрихового коду, то в ШК-знаках під час їх зчитування 3 носія гарантовано виправлятимуться однократні помилки. Для виявлення двократних помилок, а також помилок більшої кратності в ШКзнаках слід використовувати неповні многозначні коди Хемінга.

Таким чином, необхідно вирішити задачу синтезу символік багатоколірних штрихових кодів 3 можливістю виправлення однократних та виявлення багатократних помилок у зчитуваних ШК-знаках коли кількість $q$ кольорів, використовуваних для розфарбовування штрихкодових елементів, є степенем простого числа.

\section{Синтез символіки багатоколірного завадостійкого штрихового коду} на основі q-кового коду Хемінга. Структурно ШК-знак (рис. 1), до складу якого входять $s$ елементів, має складатися з $u$ інформаційних елементів (розрядів), які утворюють інформаційне слово $B=\left(b_{1} b_{2} \ldots b_{u}\right)$ та $v$ контрольних елементів (розрядів), які утворюють контрольне слово $T=\left(t_{1} t_{2} \ldots t_{v}\right)$, де $u+v=s$, а кодове слово $Z$, яке $є$ вектором ШК-знака, формують як $Z:=B \vdots T$.

Побудову символіки завадостійкого штрихового коду виконаємо на основі перевірної матриці $Н$ коду Хемінга.

У загальному випадку перевірна матриця $q$-кового $(s, u)$-коду Хемінга має вигляд:

$$
H_{(s, u)}^{" q u}=\left\|\begin{array}{cccccccc}
h_{11} & h_{12} & \cdots & h_{1 u} & 1 & 0 & \cdots & 0 \\
h_{21} & h_{22} & \cdots & h_{2 u} & 0 & 1 & \cdots & 0 \\
\vdots & \vdots & \vdots & \vdots & \vdots & \vdots & \vdots & \vdots \\
h_{v 1} & h_{v 2} & \cdots & h_{v u} & 0 & 0 & \cdots & 1
\end{array}\right\|=\left\|H_{v \times u} \mid I_{v}\right\|,
$$

де $h_{i j} \in\{0,1,2, \ldots, q-1\}$.

Стовпці матриці $H_{(s, u)}^{\prime \prime}$, максимальна кількість яких становить $\left(q^{v}-1\right) /(q-1), \epsilon$ ненульовими $v$-розрядними послідовностями, у яких перша 
«Системні технології» 1 (132) 2021 «System technologies»

ненульова компонента дорівнює одиниці. Ця умова забезпечує попарну лінійну незалежність стовпців $[11,12]$, а параметри $u$ i $v$ пов’язані між собою співвідношенням

$$
u \leq \frac{q^{v}-1}{q-1}-v
$$

Многозначний $(s, u)$-код Хемінга називають повним, якщо у співвідношенні (2) виконується рівність. Якщо ж у підматриці $H_{v \times u}$ (див. (1)) викреслити один або декілька стовпців, то код Хемінга стане неповним.

Якщо виконати перебір всіх можливих значень вектора $B$ - від (0 $0 \ldots 0)$ до $(q-1 q-1 \ldots q-1)$, де $q=p^{m}$, то на основі матриці $H_{(s, u)}^{\prime \prime}$ можна згенерувати всі можливі кодові слова $Z=\left(z_{1} z_{2} \ldots z_{s}\right) q$-кового $(s, u)$-коду Хемінга, кожне з яких отримують як

$$
Z:=B:\left(B \cdot H_{v \times u}^{T}\right)
$$

Кількість можливих кодових слів $Z$ становить $q^{u}$, а величина $q^{u} \in$ потужністю символіки багатоколірного штрихового коду.

Кожному $Z$ необхідно поставити у відповідність ШК-знак, розфарбувавши його елементи відповідними кольорами. При цьому кожен ШК-знак буде завадостійким. Якщо вектори $Z$ згенерувати на основі перевірної матриці повного коду Хемінга, то під час зчитування штрихкодової позначки у межах кожного ШК-знака можливе виправлення однократної помилки (корекція одного елемента). Якщо вектори $Z$ згенерувати на основі неповного коду Хемінга, то у межах кожного ШК-знака можливе або виправлення однократної помилки (спотворення одного елемента), або виявлення значної кількості багатократних спотворень.

У табл. 1 наведено деякі повні $(s, u)$-коди Хемінга, на основі яких можна синтезувати символіки завадостійких штрихових кодів при використанні для розфарбовування елементів 4-х, 8-ми та 9-ти кольорів.

\section{Таблиця 1}

Деякі повні $q$-кові $(s, u)$-коди Хемінга

коли $q \in$ степенем простого числа

\begin{tabular}{|c|c|c|}
\hline \multicolumn{3}{|c|}{ Кількість використовуваних кольорів } \\
\hline$q=4$ & $q=8$ & $q=9$ \\
\hline \multicolumn{3}{|c|}{ Вид скінченного поля } \\
\hline$G F\left(2^{2}\right)$ & $G F\left(2^{3}\right)$ & $G F\left(3^{2}\right)$ \\
\hline$(5,3)-$ & $(9,7)-$ & $(10,8)-$ \\
$(21,18)-$ & $(73,70)-$ & $(91,88)-$ \\
\hline
\end{tabular}


«Системні технологіï» 1 (132) 2021 «System technologies»

Розглянемо випадок побудови символіки 4-колірного завадостійкого штрихового коду. Для цієї мети скористаємось четвірковими кодами Хемінга.

Спочатку візьмемо четвірковий повний $(5,3)$-код Хемінга (див. табл. 1), якому відповідає перевірна матриця

$$
\begin{aligned}
& \begin{array}{lllll}
b_{1} & b_{2} & b_{3} & t_{1} & t_{2}
\end{array} \\
& H_{(5,3)}^{4 "}=\left\|\begin{array}{lllll}
1 & 1 & 1 & 1 & 0 \\
1 & 2 & 3 & 0 & 1
\end{array}\right\| \text {. }
\end{aligned}
$$

Такий код дозволяє побудувати $N=4^{3}=64$ різні чотириколірні ШК-знаки 3 можливістю виправлення однократних помилок у ШК-знаках під час їх зчитування 3 носія.

Операції кодування-декодування в цьому випадку виконують у полі $G F\left(2^{2}\right)$ за модулем двійкового незвідного многочлена степеня два. Існує єдиний незвідний многочлен степеня два - це $p_{2}^{(2)}(x)=x^{2}+x+1$ [13].

Для побудови поля спочатку слід взяти $G F(2)$, а потім на основі $p_{2}^{(2)}(x)$ сформувати його розширення $G F\left(2^{2}\right)$ (табл. 2).

Таблиця 2

Подання елементів поля $G F\left(2^{2}\right)$ за модулем незвідного

многочлена $p_{2}^{(2)}(x)=x^{2}+x+1$

\begin{tabular}{|c|c|c|c|c|}
\hline $\begin{array}{c}\text { У вигляді } \\
\text { невід'ємного } \\
\text { показника } \\
\text { степеня } \alpha\end{array}$ & $\begin{array}{c}\text { У вигляді } \\
\text { від'ємного } \\
\text { показника } \\
\text { степеня } \alpha\end{array}$ & $\begin{array}{c}\text { У вигляді } \\
\text { многочлена } \\
\text { від } \alpha\end{array}$ & $\begin{array}{c}\mathrm{y} \\
\text { двійковому } \\
\text { вигляді }\end{array}$ & $\begin{array}{c}\mathrm{y} \\
\text { десятковому } \\
\text { вигляді }\end{array}$ \\
\hline 0 & 0 & 0 & 00 & 0 \\
$\alpha^{0}$ & $\alpha^{-3}$ & 1 & 01 & 1 \\
$\alpha^{1}$ & $\alpha^{-2}$ & $\alpha$ & 10 & 2 \\
$\alpha^{2}$ & $\alpha^{-1}$ & $\alpha+1$ & 11 & 3 \\
\hline
\end{tabular}

У табл. $2 \alpha$ - примітивний елемент поля $G F\left(2^{2}\right)$. У полі $G F\left(2^{2}\right) \alpha^{3}=\alpha^{0}=\alpha^{-3}=1$.

Приклади виконання операцій у $G F\left(2^{2}\right)$ :

додавання: $2+3=\alpha+(\alpha+1)=2 \alpha+1=1$,

множення: $2 \cdot 3=\alpha^{1} \cdot \alpha^{2}=\alpha^{3}=\alpha^{0}=1$,

ділення: $2: 3=\alpha^{1}: \alpha^{2}=\alpha^{1} \cdot \alpha^{-2}=\alpha^{-1}=3$.

Для зручності можна користуватись табличним способом виконання операцій (рис. 2).

у полі $G F\left(2^{2}\right)$ для кожного ненульового елемента $b$ iснує протилежний (адитивно обернений) елемент $-b$ такий, що $b+(-b)=0.3$ таблиці додавання на рис. 2 видно, що протилежний до елемента $1 \epsilon$ елемент 1 , протилежним до 
«Системні технологіï» 1 (132) 2021 «System technologies»

елемента $2 \epsilon$ елемент 2, а протилежним до елемента $3 \epsilon$ елемент 3 . Це означає, що в алгебраїчних виразах у полі $G F\left(2^{2}\right)$ знак - (мінус) можна замінити на знак + (плюс). Дійсно, таблиці додавання та віднімання елементів поля співпадають (див. рис. 2). Крім того, додавання елементів поля $G F\left(2^{2}\right)$ можна виконувати як порозрядне додавання двійкових кодів цих елементів.

\begin{tabular}{c|ccccc|ccccc|ccccc|cccc}
+ & 0 & 1 & 2 & 3 & - & 0 & 1 & 2 & 3 & $\cdot$ & 0 & 1 & 2 & 3 & $:$ & 0 & 1 & 2 & 3 \\
\hline 0 & 0 & 1 & 2 & 3 & 0 & 0 & 1 & 2 & 3 & 0 & 0 & 0 & 0 & 0 & 0 & - & 0 & 0 & 0 \\
1 & 1 & 0 & 3 & 2 & 1 & 1 & 0 & 3 & 2 & 1 & 0 & 1 & 2 & 3 & 1 & - & 1 & 3 & 2 \\
2 & 2 & 3 & 0 & 1 & 2 & 2 & 3 & 0 & 1 & 2 & 0 & 2 & 3 & 1 & 2 & - & 2 & 1 & 3 \\
3 & 3 & 2 & 1 & 0 & 3 & 3 & 2 & 1 & 0 & 3 & 0 & 3 & 1 & 2 & 3 & - & 3 & 2 & 1
\end{tabular}

Рисунок 2 - Виконання операцій в полі $G F\left(2^{2}\right)$

На основі матриці $H_{(5,3)}^{4 "}$ (див. (3)) побудуємо символіку 4-колірного завадостійкого штрихового коду з можливістю корекції однократних помилок у ШК-знаках.

ШК-знаки складаються з 5-ти елементів (рис. 3), кожен елемент може бути розфарбований одним з чотирьох кольорів. ШК-знаку відповідає вектор $Z$ ШКзнака $Z=\left(z_{1} z_{2} z_{3} z_{4} z_{5}\right)$, у якому $\left(z_{1} z_{2} z_{3}\right):=\left(b_{1} b_{2} b_{3}\right),\left(z_{4} z_{5}\right):=\left(t_{1} t_{2}\right)$.

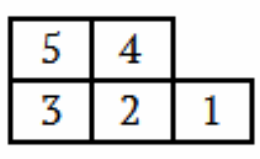

$a$

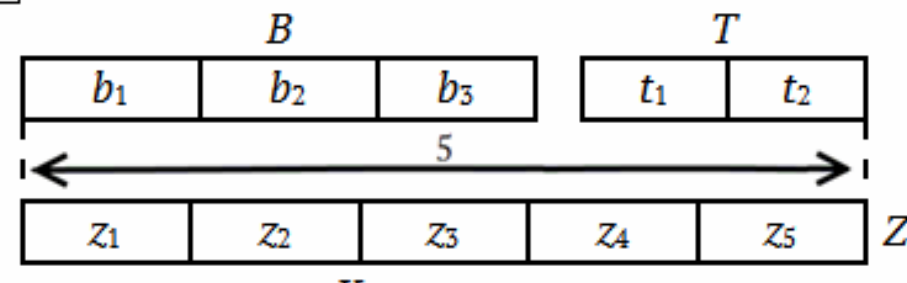

Кодове слово

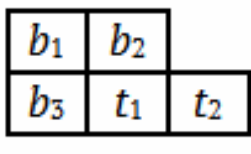

8

б

Рисунок 3 - Формування ШК-знаків чотириколірного завадостійкого штрихового коду: $a$ - структура ШК-знака; 6 - вектор ШК-знака;

в - порядок заповнення ШК-знака

Контрольні розряди обчислимо на основі матриці (3):

$$
\left\{\begin{array}{l}
t_{1}=\left(b_{1}+b_{2}+b_{3}\right) \bmod p_{2}^{(2)}(x), \\
t_{2}=\left(b_{1}+2 b_{2}+3 b_{3}\right) \bmod p_{2}^{(2)}(x) .
\end{array}\right.
$$

Нехай $B=\left(\begin{array}{lll}3 & 0 & 1\end{array}\right)$. Тоді

$$
\left\{\begin{array}{l}
t_{1}=(3+0+1) \bmod p_{2}^{(2)}(x)=2, \\
t_{2}=(3+2 \cdot 0+3 \cdot 1) \bmod p_{2}^{(2)}(x)=0 .
\end{array}\right.
$$




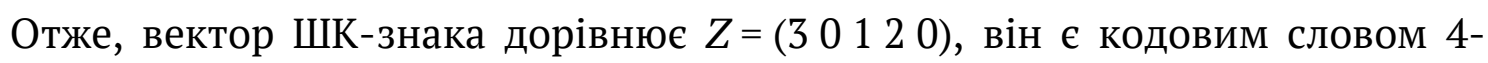
кового $(5,3)$-коду Хемінга, і йому відповідає 4-колірний завадостійкий ШКзнак (рис. 4).

\begin{tabular}{|l|l|l|}
\hline$b_{1}$ & $b_{2}$ & \multicolumn{1}{|}{} \\
\hline$b_{3}$ & $t_{1}$ & $t_{2}$ \\
\hline
\end{tabular}

$a$

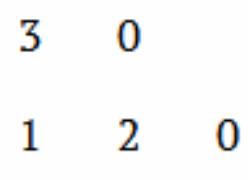

б

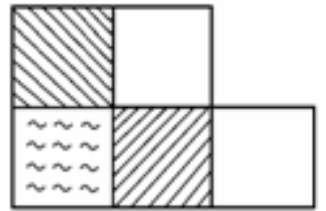

8

Рисунок 4 - Приклад створення 4-колірного завадостійкого ШКзнака: $a$ - порядок заповнення ШК-знака; б - вектор ШК-знака; в - розфарбовування ШК-знака

Для отримання символіки потужності 64 ШК-знаки завадостійкого чотириколірного штрихового коду, в якому в ШК-знаках можливе виправлення однократних помилок, необхідно взяти всі можливі значення вектора $B$ - від 000 до 3 3 3, та застосувати до кожного слова процедуру кодування.

Процес синтезу символіки можна задати узагальненим алгоритмом:

for $B=000$ to 333 do

$$
\begin{aligned}
& Z[1 . .3]:=B \\
& t_{1}=\left(\sum_{j=1}^{3} b_{j}\right) \bmod p_{2}^{(2)}(x) \\
& t_{2}=\left(\sum_{j=1}^{3} j \cdot b_{j}\right) \bmod p_{2}^{(2)}(x) \\
& Z[4]:=t_{1} ; \quad Z[5]:=t_{2} \\
& Z[1 . .5] \Rightarrow \text { barcode_pattern }(B),
\end{aligned}
$$

де barcode_pattern $(B)$ - програмна процедура перетворення цифрового вектора $Z$ ШК-знака в 4-колірне зображення ШК-знака (рис. 48).

Отриманій символіці можна поставити у відповідність числову множину $\Omega=\{0,1,2, \ldots, 63\}$ (табл. 3).

Під час створення штрихкодового зображення вхідну алфавітно-цифрову послідовність (символи $A S C I I)$ перетворюють у числову послідовність, до складу якої входять числа з діапазону 0-63, а потім кожному числу ставлять у відповідність ШК-знак з табл. 3. 
«Системні технології» 1 (132) 2021 «System technologies»

Таблиця 3

Структура символіки завадостійкого чотириколірного штрихового коду

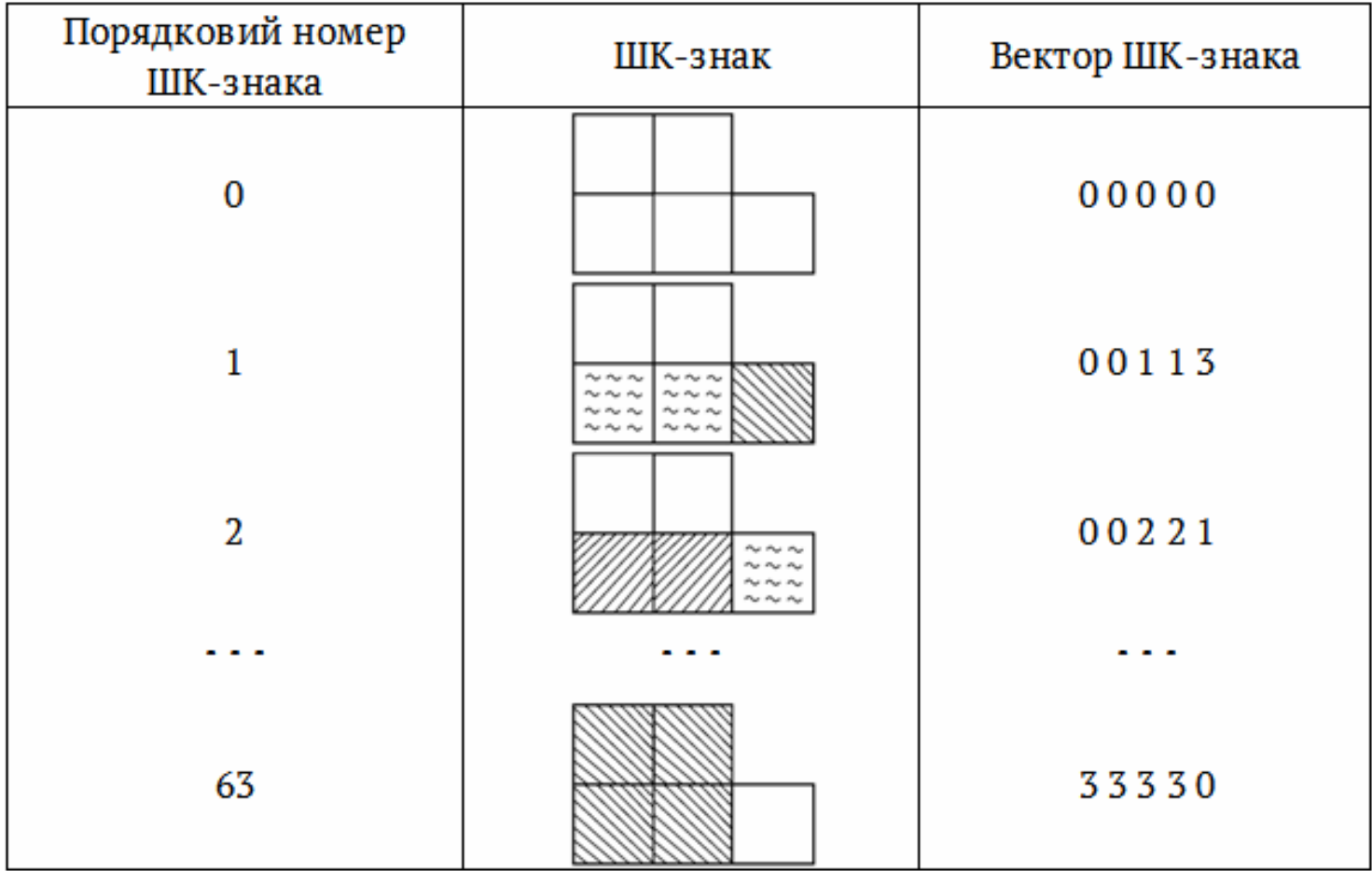

Для синтезу восьмиколірних завадостійких ШК-знаків слід використовувати вісімкові коди Хемінга. При цьому операції кодування-декодування виконують у полі $G F\left(2^{3}\right)$ за модулем незвідного многочлена степеня три. Існують два такі многочлени: $x^{3}+x+1$ та $x^{3}+x^{2}+1$; будь-який 3 них можна обрати для побудови поля (табл. 4).

У полі $G F\left(2^{3}\right) \alpha^{7}=\alpha^{0}=\alpha^{-7}=1$, а додавання та віднімання елементів поля можна виконувати як порозрядне додавання двійкових кодів цих елементів.

Для синтезу дев’ятиколірних завадостійких ШК-знаків необхідно використовувати дев’яткові коди Хемінга. При цьому операції кодування-декодування виконують у полі $G F\left(3^{2}\right)$ за модулем трійкового многочлена степеня два.

Для побудови поля $G F\left(3^{2}\right)$ необхідно взяти поле $G F(3)$, елементами якого $€$ $0,1,2$, та незвідний трійковий многочлен $p_{3}^{(2)}(x)$ степеня два, коефіцієнти якого $є$ елементами поля $G F(3)$. Таким многочленом оберемо, наприклад, $p_{3}^{(2)}(x)=x^{2}+x+2$, він дозволяє отримати розширення $G F\left(3^{2}\right)$ поля (табл. 5). Операції над коефіцієнтами виконують за модулем три. 
«Системні технологіï» 1 (132) 2021 «System technologies»

Таблиця 4

Подання елементів поля $G F\left(2^{3}\right)$ за модулем незвідного

многочлена $p_{2}^{(3)}(x)=x^{3}+x+1$

\begin{tabular}{|c|c|c|c|c|}
\hline $\begin{array}{c}\text { У вигляді } \\
\text { невід'ємного } \\
\text { показника } \\
\text { степеня } \alpha\end{array}$ & $\begin{array}{c}\text { У вигляді } \\
\text { від'ємного } \\
\text { показника } \\
\text { степеня } \alpha\end{array}$ & $\begin{array}{c}\text { У вигляді } \\
\text { многочлена } \\
\text { від } \alpha\end{array}$ & $\begin{array}{c}\mathrm{y} \\
\text { двійковому } \\
\text { вигляді }\end{array}$ & $\begin{array}{c}\mathrm{y} \\
\text { десятковому } \\
\text { вигляді }\end{array}$ \\
\hline 0 & 0 & 0 & 000 & 0 \\
$\alpha^{0}$ & $\alpha^{-7}$ & 1 & 001 & 1 \\
$\alpha^{1}$ & $\alpha^{-6}$ & $\alpha$ & 010 & 2 \\
$\alpha^{2}$ & $\alpha^{-5}$ & $\alpha^{2}$ & 100 & 4 \\
$\alpha^{3}$ & $\alpha^{-4}$ & $\alpha+1$ & 011 & 3 \\
$\alpha^{4}$ & $\alpha^{-3}$ & $\alpha^{2}+\alpha$ & 110 & 6 \\
$\alpha^{5}$ & $\alpha^{-2}$ & $\alpha^{2}+\alpha+1$ & 111 & 7 \\
$\alpha^{6}$ & $\alpha^{-1}$ & $\alpha^{2}+1$ & 101 & 5 \\
\hline
\end{tabular}

Таблиця 5

Подання елементів поля $G F\left(3^{2}\right)$ за модулем незвідного

многочлена $p_{3}^{(2)}(x)=x^{2}+x+2$

\begin{tabular}{|c|c|c|c|c|}
\hline $\begin{array}{c}\text { У вигляді } \\
\text { невід'ємного } \\
\text { показника } \\
\text { степеня } \alpha\end{array}$ & $\begin{array}{c}\text { У вигляді } \\
\text { від'ємного } \\
\text { показника } \\
\text { степеня } \alpha\end{array}$ & $\begin{array}{c}\text { У вигляді } \\
\text { многочлена } \\
\text { від } \alpha\end{array}$ & $\begin{array}{c}\text { У трійковому } \\
\text { вигляді }\end{array}$ & $\begin{array}{c}\mathrm{y} \\
\text { десятковому } \\
\text { вигляді }\end{array}$ \\
\hline 0 & 0 & 0 & 00 & 0 \\
$\alpha^{0}$ & $\alpha^{-8}$ & 1 & 01 & 1 \\
$\alpha^{1}$ & $\alpha^{-7}$ & $\alpha$ & 10 & 3 \\
$\alpha^{2}$ & $\alpha^{-6}$ & $2 \alpha+1$ & 21 & 7 \\
$\alpha^{3}$ & $\alpha^{-5}$ & $2 \alpha+2$ & 22 & 8 \\
$\alpha^{4}$ & $\alpha^{-4}$ & 2 & 02 & 2 \\
$\alpha^{5}$ & $\alpha^{-3}$ & $2 \alpha$ & 20 & 6 \\
$\alpha^{6}$ & $\alpha^{-2}$ & $\alpha+2$ & 12 & 5 \\
$\alpha^{7}$ & $\alpha^{-1}$ & $\alpha+1$ & 11 & 4 \\
\hline
\end{tabular}

Декодування багатоколірних завадостійких ШК-знаків. Під час зчитування 3 носія штрихкодового зображення послідовно виокремлюють ШКзнаки, кожному з яких ставлять у відповідність $q$-ковий $s$-розрядний вектор ШК-знака $Z^{\prime}=\left(z_{1}^{\prime} z_{2}^{\prime} \ldots z_{s}^{\prime}\right)$, який декодують за правилами $q$-кового $(s, u)$-коду Хемінга.

Наприклад, під час зчитування чотириколірного штрихового коду, символіка якого побудована на основі 4-кового $(5,3)$-коду Хемінга, кожному ШКзнаку ставлять у відповідність 5-розрядний вектор ШК-знака $Z^{\prime}=\left(z_{1}^{\prime} z_{2}^{\prime} z_{3}^{\prime} z_{4}^{\prime} z_{5}^{\prime}\right)$. Декодування кожного вектора $Z^{\prime}$ виконують за правилами четвіркового (5, 3)-коду Хемінга.

На основі матриці (3) обчислимо синдром помилки $S=\left(S_{1} S_{2}\right)$ : 
«Системні технологіï» 1 (132) 2021 «System technologies»

$$
\left\{\begin{array}{l}
S_{1}=\left(z_{1}^{\prime}+z_{2}^{\prime}+z_{3}^{\prime}-z_{4}^{\prime}\right) \bmod p_{2}^{(2)}(x), \\
S_{2}=\left(z_{1}^{\prime}+2 z_{2}^{\prime}+3 z_{3}^{\prime}-z_{5}^{\prime}\right) \bmod p_{2}^{(2)}(x) .
\end{array}\right.
$$

У системі (4) знак мінус можна замінити на знак плюс.

Корекцію прийнятого вектора $Z^{\prime}$ (зчитаного ШК-знака) виконують наступним чином.

Якщо $S=0$, то вважають, що вектор $Z^{\prime} \in$ кодовим словом $\left(Z=Z^{\prime}\right)$, і зчитаний ШК-знак не містить спотворених елементів.

Нехай зчитано ШК-знак, вектор якого дорівнює $Z^{\prime}=\left(\begin{array}{llll}3 & 0 & 1 & 2\end{array}\right)$.

Обчислимо синдром помилки на основі системи (4):

$$
\left\{\begin{array}{l}
S_{1}=(3+0+1+2) \bmod p_{2}^{(2)}(x)=0, \\
S_{2}=(3+2 \cdot 0+3 \cdot 1+0) \bmod p_{2}^{(2)}(x)=0 .
\end{array}\right.
$$

Оскільки $S=0$, то прийнятий вектор $Z^{\prime} \epsilon$ кодовим словом $(5,3)$-коду Хемінга, i, отже, відповідний зчитаний ШК-знак не містить спотворень.

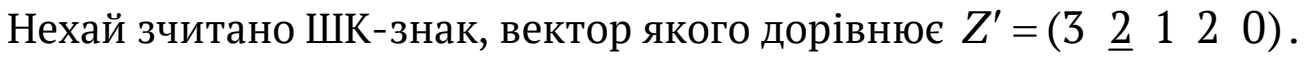

Обчислимо синдром помилки на основі (4):

$$
\left\{\begin{array}{l}
S_{1}=(3+2+1+2) \bmod p_{2}^{(2)}(x)=2, \\
S_{2}=(3+2 \cdot 2+1 \cdot 3+0) \bmod p_{2}^{(2)}(x)=3 .
\end{array}\right.
$$

Оскільки $S_{1}=2$, то величина е помилки дорівнює $2\left(e=S_{1}=2\right)$. Величиною помилки є перша ненульова компонента синдрому.

Компоненти синдрому поділимо на величину помилки (на 2), щоб визначити локатор помилки: $\left(\begin{array}{l}2 \\ 2\end{array}\right) / e=\left(\begin{array}{ll}2 / 2 & 3 / 2\end{array}\right) \bmod p_{2}^{(2)}(x)=\left(\begin{array}{ll}1 & 2\end{array}\right)$.

Оскільки локатор (12) збігається 3 другим стовпцем матриці $H_{(5,3)}^{4 "}$ (див. (3)), то вектор $Z^{\prime}$ містить помилку в розряді $Z_{2}^{\prime}$.

Виправимо помилку в 2-му розряді вектора $Z^{\prime}$ :

$$
z_{2}=\left(z_{2}^{\prime}-e\right) \bmod p_{2}^{(2)}(x)=\left(z_{2}^{\prime}+e\right) \bmod p_{2}^{(2)}(x)=(2+2) \bmod p_{2}^{(2)}(x)=0 \text {. }
$$

Правильним вектором зчитаного ШК-знака $є Z=\left(\begin{array}{llll}3 & 0 & 1 & 2\end{array}\right)$.

Четвірковий $(5,3)$-код Хемінга гарантовано забезпечує виправлення однократних помилок у ШК-знаках, однак він не виявляє двократні помилки, а також помилки більшої кратності, оскільки є повним кодом.

Будь-який многозначний повний код Хемінга не забезпечує виявлення двократної помилки. Але якщо застосовувати многозначні неповні коди Хемінга, то можна виявляти частину двократних помилок, а також помилок більшої кратності.

Синтез символік багатоколірних завадостійких штрихових кодів на основі многозначних неповних кодів Хемінга. Неповний код Хемінга можна отримати шляхом викреслювання відповідної кількості стовпців у підматриці $H_{v \times u}$ перевірної матриці $H_{(s, u)}^{\prime q "}$ повного коду Хемінга (див. (1)). 
«Системні технології» 1 (132) 2021 «System technologies»

Наприклад, на основі четвіркового повного $(5,3)$-коду Хемінга, який задають перевірною матрицею $H_{(5,3)}^{4 "}$ (див. (3)), можна утворити неповний $(4,2)$ код Хемінга - якщо викреслити стовпець $b_{3}$ у перевірній матриці $H_{(5,3)}^{\prime \prime}$. На основі неповного $(4,2)$-коду можна отримати символіку потужності 16 штрихового коду (табл. 6).

Неповні четвіркові коди Хемінга можна отримати також, виходячи 3 повного $(21,18)$-коду (див. табл. 1$)$.

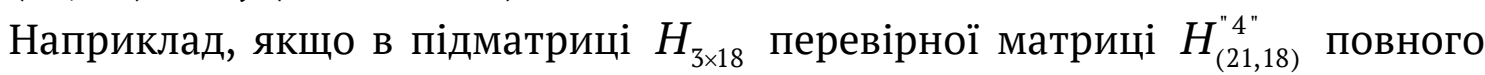
коду викреслити 13 стовпців, то отримаємо четвірковий неповний $(8,5)$-код Хемінга, на основі якого можна синтезувати символіку потужності 1024 ШКзнаки завадостійкого 4-колірного штрихового коду (табл. 6).

Таблиця 6

Параметри символік чотириколірних завадостійких штрихових кодів на основі неповних четвіркових $(s, u)$-кодів Хемінга

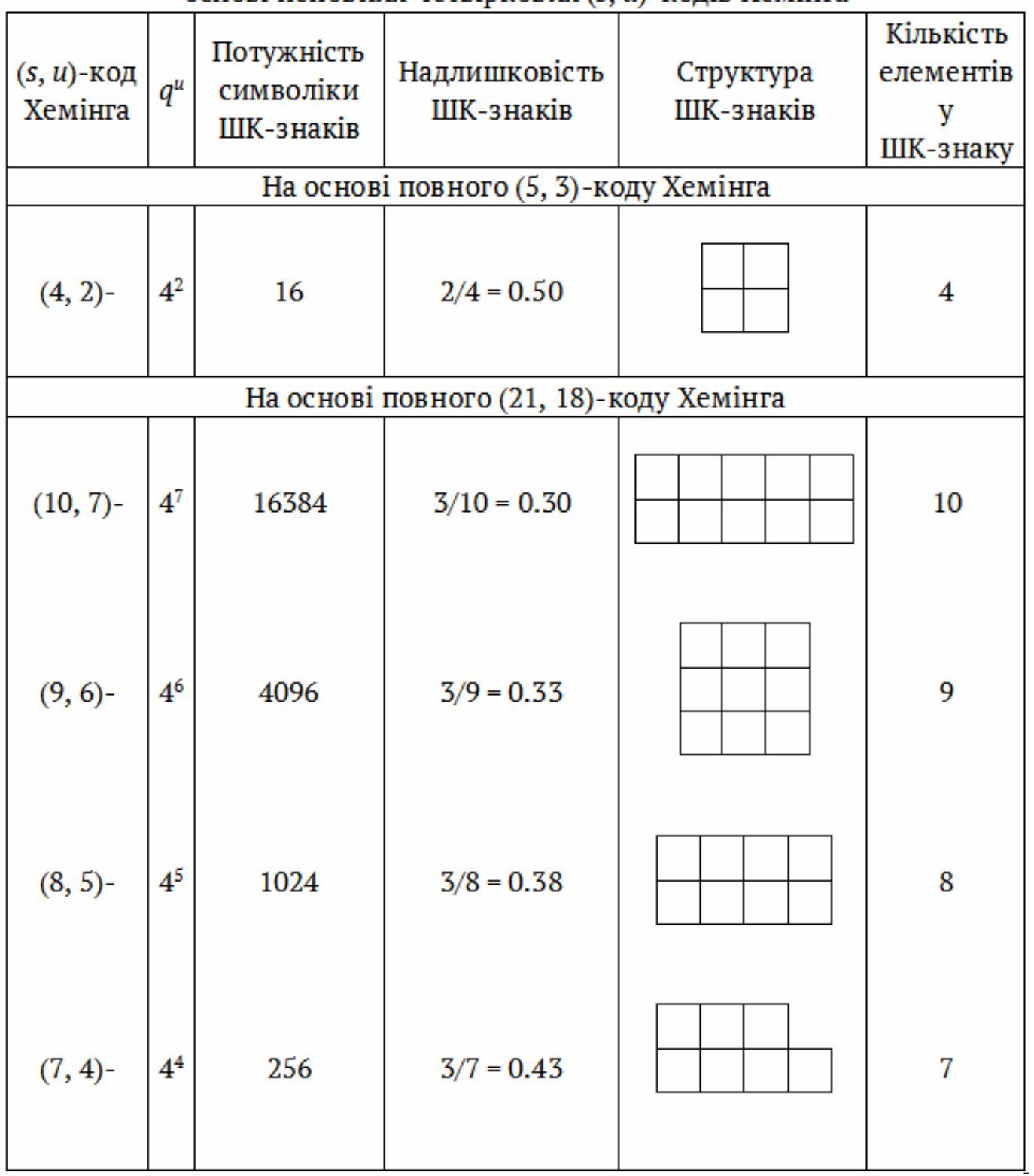


«Системні технологіï» 1 (132) 2021 «System technologies»

Неповні вісімкові коди Хемінга можна отримати, виходячи 3 повного $(9,7)$-коду (табл. 1). Для синтезу символік восьмиколірних завадостійких штрихових кодів на основі повного $(9,7)$-коду можна отримати чотири вісімкові неповні коди (табл. 7).

Таблиця 7

Параметри символік восьмиколірних завадостійких штрихових кодів на основі вісімкових $(s, u)$-кодів Хемінга

\begin{tabular}{|c|c|c|c|c|c|}
\hline $\begin{array}{c}(s, u) \text {-код } \\
\text { Хемінга }\end{array}$ & $q^{u}$ & $\begin{array}{l}\text { Потужність } \\
\text { символіки } \\
\text { ШК-знаків }\end{array}$ & $\begin{array}{c}\text { Надлишковість } \\
\text { ШК-знаків }\end{array}$ & $\begin{array}{l}\text { Структура } \\
\text { ШК-знаків }\end{array}$ & $\begin{array}{c}\text { Кількість } \\
\text { елементів } \\
\text { у } \\
\text { ШК-знаку }\end{array}$ \\
\hline \multicolumn{6}{|c|}{ На основі повного $(9,7)$-коду Хемінга } \\
\hline$(7,5)-$ & $8^{5}$ & 32768 & $2 / 7=0.29$ & & 7 \\
\hline$(6,4)-$ & $8^{4}$ & 4096 & $2 / 6=0.33$ & & 6 \\
\hline$(5,3)-$ & $8^{3}$ & 512 & $2 / 5=0.40$ & & 5 \\
\hline$(4,2)-$ & $8^{2}$ & 64 & $2 / 4=0.50$ & & 4 \\
\hline
\end{tabular}

Для того, щоб синтезувати символіки дев'ятиколірних завадостійких штрихових кодів слід розглядати дев'яткові коди Хемінга.

Розглянемо повний дев’ятковий $(10,8)$-код Хемінга (табл. 1$)$, якому відповідає перевірна матриця

$$
H_{(10,8)}^{\text {9" }^{\prime \prime}}=\left\|\begin{array}{|llllllllll}
b_{1} & b_{2} & b_{3} & b_{4} & b_{5} & b_{6} & b_{7} & b_{8} & t_{1} & t_{2} \\
1 & 1 & 1 & 1 & 1 & 1 & 1 & 1 & 1 & 0 \\
1 & 2 & 3 & 4 & 5 & 6 & 7 & 8 & 0 & 1
\end{array}\right\|=\left\|H_{2 \times 8} \quad I_{2}\right\| .
$$

На основі цього повного коду отримаємо чотири дев’яткові неповні коди, які можна використати для синтезу символік дев'ятиколірних завадостійких штрихових кодів. Їх отримують викреслюванням відповідної кількості стовпців у підматриці $H_{2 \times 8}$ повного коду. Це такі неповні дев'яткові коди Хемінга: $(7,5) ;(6,4)-;(5,3)-$ та $(4,2)$-код. 
«Системні технології» 1 (132) 2021 «System technologies»

Наприклад, викресливши стовпці b4 - b8 отримаємо перевірну матрицю дев'яткового неповного $(5,3)$-коду Хемінга:

$$
H_{(5,3)}^{\text {9" }^{\prime \prime}}=\left\|\begin{array}{ccccc}
b_{1} & b_{2} & b_{3} & t_{1} & t_{2} \\
1 & 1 & 1 & 1 & 0 \\
1 & 2 & 3 & 0 & 1
\end{array}\right\| .
$$

Дослідимо здатність виявляти двократні помилки цим кодом.

Нехай на носій було нанесено ШК-знак, вектор якого дорівнював $\mathrm{Z}=\left(\begin{array}{lll}5 & 1 & 8\end{array} 2\right.$ 3), а внаслідок ушкоджень штрихкодового зображення з носія зчита-

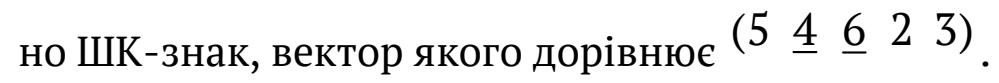

Обчислимо синдром помилки на основі матриці (5):

$\left\{\begin{array}{l}S_{1}=(5+4+6-2) \bmod p_{3}^{(2)}(x)=4, \\ S_{2}=(5 \cdot 1+4 \cdot 2+6 \cdot 3-3) \bmod p_{3}^{(2)}(x)=0 .\end{array}\right.$

Оскільки $\mathrm{S} 1$ = 4, то величина помилки дорівнює 4 .

Для визначення локатора помилки компоненти синдрому поділимо на величину помилки:

$\left(\begin{array}{ll}4 & 0\end{array}\right) / e=\left(\begin{array}{ll}4 / 4 & 0 / 4\end{array}\right) \bmod p_{3}^{(2)}(x)=\left(\begin{array}{ll}1 & 0\end{array}\right)$

Локатор (1 0) збігається зі стовпцем t1 матриці (5), вказуючи на те, що помилка міститься в розряді $z_{4}^{\prime}$ прийнятого слова. Однак це помилкове рішення, оскільки ушкодженими є розряди $z_{2}^{\prime}$ та $z_{3}^{\prime}$.

Тому таку двократну помилку виявлено не буде.

Розглянемо інший приклад.

Нехай зчитано ШК-знак, вектор якого дорівнює $Z^{\prime}=\left(\begin{array}{llll}4 & \underline{3} & 8 & 2\end{array}\right)$;; він містить дві помилки - у 1-му та 2-му розрядах.

На основі матриці (5) обчислимо компоненти синдрому:

$\left\{\begin{array}{l}S_{1}=(4+3+8-2) \bmod p_{3}^{(2)}(x)=4, \\ S_{2}=(4 \cdot 1+3 \cdot 2+8 \cdot 3-3) \bmod p_{3}^{(2)}(x)=6 .\end{array}\right.$

Величина помилки дорівнює $4(\mathrm{e}=\mathrm{S} 1=4)$.

Обчислимо локатор помилки:

$(4 / 46 / 4) \bmod p_{3}^{(2)}(x)=(15)$ 
«Системні технології» 1 (132) 2021 «System technologies»

Оскільки локатор (1 5) не збігається з жодним зі стовпців матриці (5), то це означає, що прийнятий вектор $Z^{\prime}$ містить двократну помилку; помилку виявлено.

За допомогою комп’ютерного моделювання процесів декодування прийнятих векторів ШК-знаків, що містять помилки, з'ясовуємо, що в значній частині випадків багатократні помилки виявляються.

Так, у ШК-знаках, синтезованих на основі четвіркового неповного $(8,5)$ коду Хемінга виявляються 50\% двократних помилок (рис. 5), а також велика кількість помилок більшої кратності (табл. 8).

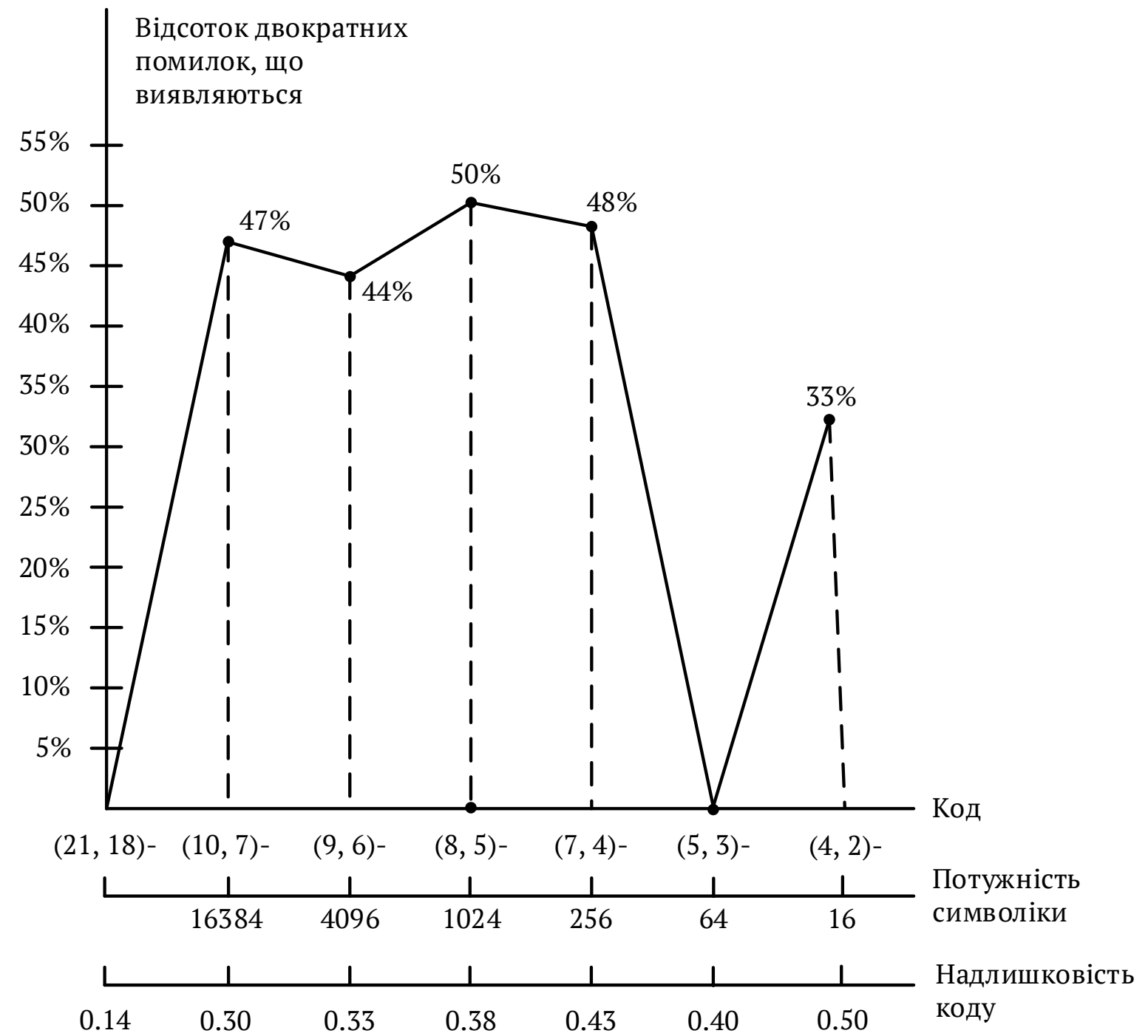

Рисунок 5 - Ступінь виявлення двократних помилок у чотириколірних ШКзнаках, синтезованих на основі деяких четвіркових неповних кодів Хемінга 
«Системні технології» 1 (132) 2021 «System technologies»

Таблиця 8

Виявлення багатократних помилок у ШК-знаках чотириколірних штрихових кодів, символіки яких синтезовано на основі четвіркових неповних кодів Хемінга

\begin{tabular}{|c|c|c|c|c|c|c|}
\hline & \multirow{2}{*}{\multicolumn{6}{|c|}{ Четвірковий неповний $(s, u)$-код Хемінга }} \\
\hline & & & & & & \\
\hline & \multicolumn{4}{|c|}{$\begin{array}{l}\text { На основі повного } \\
(21,18) \text {-коду }\end{array}$} & \multicolumn{2}{|c|}{$\begin{array}{c}\text { На основі повного } \\
(5,3) \text {-коду }\end{array}$} \\
\hline & $(10,7)-$ & $(9,6)-$ & $(8,5)-$ & $(7,4)-$ & $(5,3)-$ & $(4,2)-$ \\
\hline $\begin{array}{l}\text { Потужність } \\
\text { символіки, } \\
\text { ШК-знаків }\end{array}$ & 15625 & 3125 & 1024 & 256 & 64 & 16 \\
\hline $\begin{array}{l}\text { Надлишковість } \\
\text { ШК-знаків }\end{array}$ & 0.30 & 0.33 & 0.38 & 0.43 & 0.40 & 0.50 \\
\hline \multicolumn{7}{|c|}{ Відсоток багатократних помилок, що виявляються } \\
\hline 2-кратних & $47 \%$ & $44 \%$ & $50 \%$ & $48 \%$ & $0 \%$ & $33 \%$ \\
\hline 3-кратних & $54 \%$ & $57 \%$ & $62 \%$ & $62 \%$ & $0 \%$ & $11 \%$ \\
\hline 4-кратних & $52 \%$ & $58 \%$ & $62 \%$ & $64 \%$ & $0 \%$ & $22 \%$ \\
\hline 5-кратних & $52 \%$ & $57 \%$ & $63 \%$ & $71 \%$ & $0 \%$ & - \\
\hline 6-кратних & $51 \%$ & $55 \%$ & $60 \%$ & $66 \%$ & - & - \\
\hline
\end{tabular}

Моделюванням можливих випадків спотворення елементів у ШК-знаках можна дослідити завадостійкість ШК-знаків штрихових кодів, символіки яких синтезовано на основі деяких неповних 8-кових та 9-кових кодів Хемінга, зокрема здатність виявляти двократні помилки у ШК-знаках 8-колірних та 9колірних штрихових кодів (рис. 6). У квадратних дужках вказано потужність символіки, яку породжує відповідний неповний код Хемінга.

Висновки. При використанні багатоколірних штрихових кодів у системах автоматичної ідентифікації для досягнення необхідного рівня надійності зчитуваних даних слід застосовувати дворівневу систему забезпечення завадостійкості.

На нижньому рівні (рівень ШК-знаків) доцільно використовувати многозначний неповний код Хемінга. При цьому цифрові еквіваленти ШК-знаків (вектори ШК-знаків) мають бути кодовими словами многозначного коду Хемінга, а мінімальними структурними одиницями, що обробляються, є елементи (чарунки) ШК-знака.

На верхньому рівні забезпечення завадостійкості (рівень штрихкодової позначки) доцільно використовувати многозначний коректувальний код (наприклад, код Ріда-Соломона), який виправляє багатократні спотворення двох видів - помилки та стирання. При цьому мінімальними структурними одини- 
«Системні технологіï» 1 (132) 2021 «System technologies»

цями, що обробляються, є ШК-знаки, а штрихкодова позначка сприймається як многозначне слово, розрядами якого є ШК-знаки. Помилка - це випадок (ситуація), коли невідоме ні місцезнаходження спотвореного ШК-знака у зчитаному слові, ані величина спотворення. Стирання - це випадок (ситуація), коли місцезнаходження спотвореного ШК-знака відоме, а невідомим є лише величина спотворення (стирання є математичним, а не фізичним поняттям).

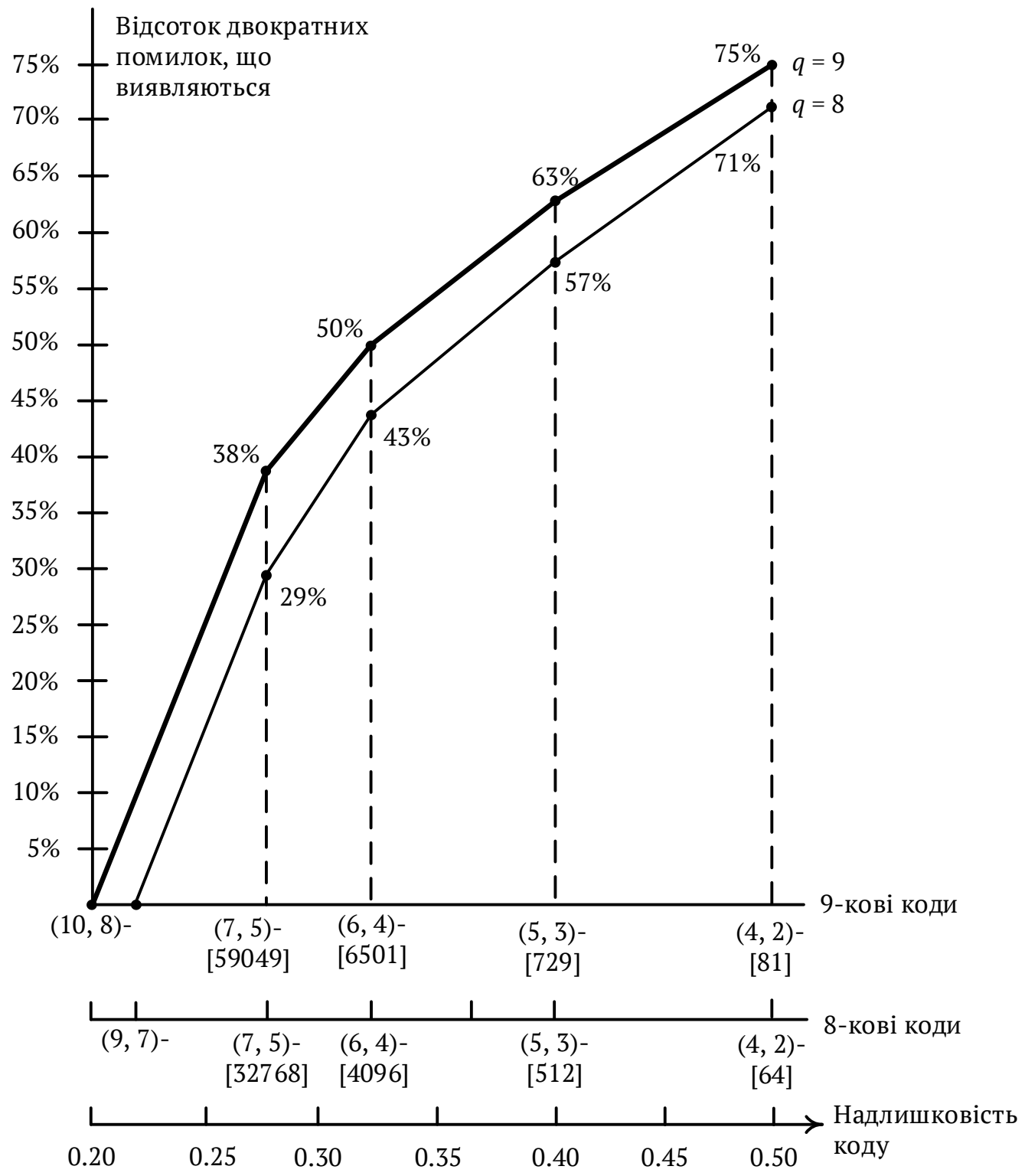

Рисунок 6 -Здатність виявляти двократні помилки у восьмиколірних $(q=8)$

та дев'ятиколірних $(q=9)$ ШК-знаках, синтезованих на основі неповних кодів Хемінга

Під час оброблення штрихкодової позначки функціонують два програмні декодери: декодер многозначного коду Хемінга - у межах кожного ШК-знака 


\section{«Системні технології» 1 (132) 2021 «System technologies»}

(внутрішній декодер); декодер коду Ріда-Соломона - у межах зчитаної штрихкодової позначки в цілому (зовнішній декодер).

Результатом внутрішнього декодування є три висновки: «неушкоджений ШК-знак», «виправлений ШК-знак», «стертий ШК-знак». Якщо синдром помилки дорівнює нулю, то приймається рішення про те, що ШК-знак не містить спотворень. Якщо в ШК-знаку ушкоджено лише один елемент, то многозначний код Хемінга виправить таке спотворення. Якщо в ШК-знаку буде ушкоджено два або більше елементів, то таке багатократне ушкодження буде або виявлене кодом Хемінга (таке має місце в (29-75)\% випадків), і декодер зідентифікує такий ШК-знак як «стертий»; або буде сприйняте декодером як однократну помилку, i, отже, буде виправлене неправильно, але на верхній рівень забезпечення завадостійкості воно надійде як «помилка».

Оскільки для виправлення кожної помилки витрачаються два контрольні розряди (символи) коду Ріда-Соломона, а для виправлення кожного стирання - один контрольний розряд, то за рахунок передачі на верхній рівень ситуацій «стирання» замість ситуацій «помилка» коректувальні можливості коду Ріда-Соломона будуть підсилені в середньому на $(14,5$ - 37,5)\%.

Таким чином, застосування многозначного неповного коду Хемінга (саме неповного, оскільки лише неповні коди дозволяють виявляти частину багатократних ушкоджень елементів ШК-знаків) у парі з многозначним кодом Ріда-Соломона у дворівневій системі забезпечення завадостійкості істотно поліпшить надійність зчитування багатоколірних штрихових кодів.

\section{ЛИТЕРАТУРА / ЛІТЕРАТУРА}

1. Sun H.-Y. The application of barcode technology on logistics and warehouse management / Hong-Ying Sun // First International Workship on Education Technology and Computer Science, 7-8 March 2009 : proceedings. Wuhan, IEEE, 2009, Vol. 3.

2. Kaminsky M.A. Barcode scanning device / M.A. Kaminsky, J. Choi, S. Lim, M.C. Palmer // U.S. Patent USD710362S1, applicant Motorola Solutions Inc. №US29/458,380; appdate 19.06.2013 ; pubdate 05.08.2014.

3. Bagherinia H. A theory of color barcodes / H. Bagherinia, R. Manduchi // In IEEE Int. Conf. Comp. Vision Workshops, 2011, Nov.6-13, P. 806-813. DOI: 10.1109/ICCVW.2011.6130335.

4. Grillo A. High capacity colored two dimensional codes / A. Grillo, A. Lentini, M. Querini, G. Italiano // In Proc. Int. Multiconf on Conp. Science Inf. Tech., pp. 709716, 2010. 


\section{«Системні технології» 1 (132) 2021 «System technologies»}

5. Wang F. Color-constant information embedding / F. Wang, R. Manduchi // In Proc. IEEE Workshop on Color and Reflectance in Imaging and Computer Vision, 2010.

6. Cattrone P. Two-dimensional color barcode and method of generating and decoding the same / P. Cattrone // U.S. Patent 7478 746, Jan. 20, 2009.

7. Parikh D. Localization and segmentation of a 2D high capacity color barcode / D. Parikh, G. Jancke // In IEEE Workshop on Applications of Computer Vision, 2008, Jan.7.

8. Miller E. Color eigenflows: Statistical modeling of joint color changes / E. Miller, K. Tieu // In Proc. of Int. Conf. on Comp. Vision (ICCV), vol.1, P. 607-614, 2001.

9. Querini M. 2D Color Barcodes for Mobile Phones / M. Querini et.al. // International Journal of Computer Science and Applications, vol. 8.N.1, P. 136-155, 2011.

10. Blahut R. Theory and Practice of Error Control Codes / Richard E. Blahut // MA: Addison-Wesley, 1983. - 500 p.

11. Peterson W. Error-Correcting Codes / W. Wesley Peterson, E. J. Weldon, Jr. // Second Edition : MIT, 1972. - 549 p.

12. Касами Т. Теория кодирования /Т. Касами, Н. Токура, Е. Ивадари, Я. Инагаки. - М.: Мир, 1978. - 576 с.

\section{REFERENCES}

1. Sun H.-Y. The application of barcode technology on logistics and warehouse management / Hong-Ying Sun // First International Workship on Education Technology and Computer Science, 7-8 March 2009 : proceedings. Wuhan, IEEE, 2009, Vol. 3.

2. Kaminsky M.A. Barcode scanning device / M.A. Kaminsky, J. Choi, S. Lim, M.C. Palmer // U.S. Patent USD710362S1, applicant Motorola Solutions Inc. №US29/458,380; appdate 19.06.2013 ; pubdate 05.08.2014.

3. Bagherinia H. A theory of color barcodes / H. Bagherinia, R. Manduchi // In IEEE Int. Conf. Comp. Vision Workshops, 2011, Nov.6-13, P. 806-813. DOI: 10.1109/ICCVW.2011.6130335.

4. Grillo A. High capacity colored two dimensional codes / A. Grillo, A. Lentini, M. Querini, G. Italiano // In Proc. Int. Multiconf on Conp. Science Inf. Tech., pp. 709716, 2010.

5. Wang F. Color-constant information embedding / F. Wang, R. Manduchi // In Proc. IEEE Workshop on Color and Reflectance in Imaging and Computer Vision, 2010.

6. Cattrone P. Two-dimensional color barcode and method of generating and decoding the same / P. Cattrone // U.S. Patent 7478 746, Jan. 20, 2009. 


\section{«Системні технологіï» 1 (132) 2021 «System technologies»}

7. Parikh D. Localization and segmentation of a 2D high capacity color barcode / D. Parikh, G. Jancke // In IEEE Workshop on Applications of Computer Vision, 2008, Jan.7.

8. Miller E. Color eigenflows: Statistical modeling of joint color changes / E. Miller, K. Tieu // In Proc. of Int. Conf. on Comp. Vision (ICCV), vol.1, P. 607-614, 2001.

9. Querini M. 2D Color Barcodes for Mobile Phones / M. Querini et.al. // International Journal of Computer Science and Applications, vol. 8.N.1, P. 136-155, 2011.

10. Blahut R. Theory and Practice of Error Control Codes / Richard E. Blahut // MA: Addison-Wesley, 1983. - 500 p.

11. Peterson W. Error-Correcting Codes / W. Wesley Peterson, E. J. Weldon, Jr. // Second Edition : MIT, 1972. - 549 p.

12. T.Kasami, N.Tokura, E.Ivadari, Y.Inagaki Theory Coding - M.: Mir, 1978. - $576 \mathrm{p}$.

Received 04.01.2021. Accepted 11.01.2021.

Обеспечение помехоустойчивости многоцветных штрихкодовых знаков на основе поля $\mathrm{GF}\left(p^{m}\right)$

Разработана методика синтеза символик многоцветных высоконадежных итриховых кодов для систем автоматической идентификации. Предложена двухуровневая система обеспечения помехоустойчивости многоцветных итрихкодовых изображений, в которой на нижнем структурном уровне (уровне штрихкодовых знаков) применяются многозначных неполные коды Хемминга, а на верхнем (уровне штрихкодового символа) коды Рида-Соломона. Выполнена оценка корректирующих возможностей многозначных неполных кодов Хемминга при их использовании в штриховом кодировании данных. Рассмотрены особенности выполнения операций в конечных полях вида $G F\left(p^{m}\right)$ при реализации процедур кодирования-декодирования данных в системах автоматической идентификации на основе многоцветных штриховых кодов.

\section{Ensuring Error Detection and Correcting of Multicolored Bar Code Patterns Based on GF $\left(p^{m}\right)$}

A method of the synthesis of symbols of multicolor highly reliable bar codes for automatic identification systems has been developed. A two-level noise immunity system for multicolor barcode images is proposed, in which multi-valued incomplete Hamming codes are used at the lower structural level (bar code patterns) and Reed-Solomon codes at the upper level (bar code symbol). The corrective capabilities of multivalued incomplete Hamming codes when used in bar coding of data are evaluated. The peculiarity of performing operations in finite fields of the form $G F\left(p^{m}\right)$ in the implementation of data encoding-decoding procedures in automatic identification systems based on multicolor barcodes is considered. 
«Системні технології» 1 (132) 2021 «System technologies»

Сулема Євгенія Станіславівна - к.т.н., доцент, доцент кафедри програмного забезпечення комп'ютерних систем Національного технічного університету України «Київський політехнічний інститут ім. Ігоря Сікорського»

Онай Микола Володимирович - к.т.н., доцент, доцент кафедри програмного забезпечення комп’ютерних систем Національного технічного університету України «Київський політехнічний інститут ім. Ігоря Сікорського».

Дичка Андрій Іванович - аспірант кафедри програмного забезпечення комп’ютерних систем Національного технічного університету України «Київський політехнічний інститут ім. Ігоря Сікорського».

Сулема Євгения Станиславовна - к.т.н., доцент, доцент кафедры программного обеспечения компьютерных систем Национального технического университета Украины «Киевский политехнический институт им. Игоря Сикорского».

Онай Николай Владимирович - к.т.н., доцент, доцент кафедры программного обеспечения компьютерных систем Национального технического университета Украины «Киевский политехнический институт им. Игоря Сикорского».

Дичка Андрей Иванович - аспирант кафедры программного обеспечения компьютерных систем Национального технического университета Украины «Киевский политехнический институт им Игоря Сикорского».

Yevgeniya Sulema - PhD, Associate Professor, Associate Professor of the Computer Systems Sofrware Department of the National Technical University of Ukraine "Igor Sikorsky Kyiv Polytechnic Institute”.

Mykola Onai - PhD, Associate Professor, Associate Professor of the Computer Systems Sofrware Department of the National Technical University of Ukraine "Igor Sikorsky Kyiv Polytechnic Institute”.

Andrii Dychka - PhD student of the Computer Systems Software Department of the National Technical University of Ukraine “Igor Sikorsky Kyiv Polytechnic Institute”. 